\title{
FILOZOFICZNE ASPEKTY TEORII DUCHOWOŚCI EKOLOGICZNEJ PAPIEŻA FRANCISZKA W ŚWIETLE FILOZOFII TOMISTYCZNEJ
}

\begin{abstract}
Streszczenie. Artykuł jest próbą wyodrębnienia i ogólnego opisu aspektów filozoficznych, zawartych w teorii duchowości ekologicznej papieża Franciszka oraz porównania ich z myślą tomistyczną, rozwijaną przez jej polskich przedstawicieli w czasach współczesnych. Aspekty te dostrzeżono na gruncie wielu dyscyplin filozoficznych, ponieważ w tego typu duchowości chodzi o stosunek człowieka do najogólniej pojętej rzeczywistości realnej, czyli do samego siebie, przyrody, kultury i religii. W toku analizy obu stanowisk zauważono liczne analogie, a także pewne rozbieżności w sposobie widzenia przyrody, osoby ludzkiej, kultury (etyki) oraz religii, które przynajmniej częściowo można tłumaczyć niejednoznacznością niektórych sformułowań papieskich.
\end{abstract}

Słowa kluczowe: duchowość ekologiczna; papież Franciszek; tomizm; przyroda; człowiek; kultura; religia

1. Wstęp. 2. Wizja przyrody. 3. Koncepcja człowieka. 4. Pogląd na kulturę. 5. Filozofia religii i filozofia Boga. 6. Podsumowanie.

\section{WSTĘP}

Papież Franciszek proponuje m.in. w swoich encyklikach i adhortacjach, stanowiących oficjalne dokumenty papieskie, pewną formę duchowości ekologicznej jako pożądany stan relacji człowieka do środowiska naturalnego, wyrażający się w przekonaniach, postawach i stylach życia, osiąganych w drodze realizacji zasad tzw. ekologii integralnej lub zrównoważonego (integralnego) rozwoju ${ }^{1}$. Na podstawie

1 Por. Franciszek, Laudato si', Watykan 2016, 202-238 (oznaczenia liczbowe w odnośnikach do dokumentów papieskich dotyczą numerów poszczególnych fragmentów tekstu zgodnie z ich oryginalną numeracją). 
wspomnianych dokumentów można zrekonstruować zarys teorii tej duchowości, której podstawę intelektualną stanowią elementy wiedzy o charakterze interdyscyplinarnym, m.in. filozoficzym, należące do zakresu badań wielu dyscyplin filozoficznych, ponieważ w papieskiej propozycji chodzi nie tylko o filozoficzny pogląd na przyrodę, ale też na najszerzej pojętą rzeczywistość.

Treści te zostaną skrótowo przedstawione i zinterpretowane w świetle poglądów czołowych współczesnych polskich tomistów, dla których takiż obszar badań jest przedmiotem refleksji filozoficznej. Także samo pojęcie duchowości ekologicznej nie jest im obce, chociaż duchowość łączyli tradycyjnie $z$ dziedziną relacji międzyosobowych, a nie ze stosunkiem do środowiska naturalnego ${ }^{2}$. Dużo zmieniło się pod wpływem kryzysu ekologicznego, dostrzeganego przez wielu filozofów tej orientacji, którzy problematykę, związaną z ochroną środowiska, podejmują i interpretują w myśl własnej filozofii jako źródło właściwego rozumienia i rozwiązywania kwestii ekologicznych, a zjawisko zanieczyszczenia środowiska naturalnego traktują jako następstwo „zanieczyszczenia” ludzkiego myślenia różnymi ideologiami $\mathrm{i}$ apriorycznymi rozstrzygnięciami, oderwanymi od prawdy ${ }^{3}$. Powodem sięgnięcia do filozofii tomistycznej jako punktu odniesienia dla analizy myśli papieskiej jest tradycyjna pozycja tomizmu w Kościele katolickim. Był on traktowany od wielu wieków jako naturalny fundament światopoglądu chrześcijańskiego, źródło mądrości, podstawa kultury i narzędzie rozumienia świata. Św. Tomasz z Akwinu był uważany za „mistrza myślenia”, „apostoła prawdy”, którego znaczenie miało być nieprzemijające, o czym był przekonany m.in. Jan Paweł II, należący do kontynuatorów jego myśli. Swój wielce pochlebny o nim sąd wyraził $\mathrm{w}$ wielu miejscach encykliki

2 Por. M. Gogacz, Wprowadzenie do etyki chronienia osób, red. A. Andrzejuk, Warszawa 1995, 7-8; T. Ślipko, Zarys etyki szczegółowej, t. 1, Kraków 1982, 392-400.

3 Por. M.A. Krąpiec, Słowo wstępne, w: A. Maryniarczyk, Metafizyka w ekologii, Lublin 1999, 9-11; A. Maryniarczyk, Metafizyka w ekologii, dz. cyt., 17. 
Fides et ratio ${ }^{4}$. Stąd wydaje się interesującą rzeczą sprawdzenie, czy to tradycyjne podejście do filozofii tomistycznej jest nadal aktualne, a jeśli tak, to w jakim stopniu jest ono realizowane.

Najważniejsze treści filozoficzne, zawarte w teorii duchowości ekologicznej Franciszka, skonfrontowane z tezami filozofii tomistycznej, dotyczą czterech podstawowych sfer rzeczywistości: przyrody, osoby ludzkiej, kultury i religii (Boga).

\section{WIZJA PRZYRODY}

W proponowanej przez Franciszka teorii duchowości ekologicznej główne miejsce zajmuje przyroda, będąca podstawowym i koniecznym punktem odniesienia dla człowieka. Przekonania filozoficzne na jej temat są tu traktowane jako fundamentalne, wpływające na ludzkie postawy, działania i oceny. W ten system przekonań zaangażowany jest znaczny fragment refleksji filozoficznej o charakterze ontologicznym i aksjologicznym.

W ontologicznej wizji Papieża na pierwszy plan wysuwa się rozumienie przyrody jako „żywego organizmu”, jedności złożonej, gdzie „wszystko ze wszystkim jest powiązane”. Na potwierdzenie tej tezy przytacza się przykłady koniecznych i powszechnych relacji pomiędzy podstawowymi jej elementami, jak przestrzeń - czas; atomy - cząstki subatomowe; to, co fizyczno-chemiczne, i to, co biologiczne. Według tej wizji nie stanowi ona systemu zamkniętego, wyizolowanego, ale jest to system niezwykle wrażliwy na inne podsystemy, na dokonujące się w nich zmiany. Pojęcie organizmu zostaje również odniesione do całego stworzonego świata oraz ludzkich wytworów jako pewnej całości, której składnikami są wszystkie byty pozaludzkie i ludzkie, indywidualne substancje i ich zespoły, tworzące najogólniejszy system, określany jako powszechna komunia

4 Por. Jan Paweł II, Fides et ratio, Watykan 1998, 3-4, 18, 43-44, 47, 51, 57-59, 61, 76, 78-79, 81, 83. 
stworzeń, uniwersalna i komunikująca się rodzina, dzięki sieci czasem niewidzialnych powiązań ${ }^{5}$.

W tej najogólniejszej wizji przyrody zawarte są wyrażenia poetyckie, sprawiające trudność w jednoznacznej interpretacji. Jedne są o charakterze antropomorfizującym, a inne deifikującym. Mają one zapewne podnieść rangę środowiska naturalnego, wzmocnić szacunek do niego i skłonić do jego podmiotowego sposobu traktowania, jaki należny jest osobie ludzkiej i temu, co święte ${ }^{6}$. Jednak obecne tu pojęcie organizmu, $\mathrm{z}$ elementami antropomorfizującymi i deifikującymi, unifikującymi i deterministycznymi, budzi duże trudności interpretacyjne w świetle filozofii tomistycznej. Uważa się je bowiem za dość charakterystyczne dla tych form duchowości ekologicznej, które czerpią inspiracje np. z New Age czy z myśli Wschodu, gdzie przyrodę traktuje się jako jeden żywy organizm, ludzi - jako część większej całości, a Ziemi przypisuje się osobowy charakter. Poglądy takie są też typowe - zdaniem Michała Hellera - dla „romantycznej” wizji przyrody, w której wszechświat pojmuje się jako organizm, $\mathrm{w}$ którym znosi się rozgraniczenia pomiędzy duchem a materią, immanencją a transcendencją oraz zamazywana jest specyfika bytu osobowego człowieka i Boga7. Stąd wydaje się, że wspomniana idea „romantyczności” jest właściwym kierunkiem rozumienia papieskich określeń, ponieważ pełne metafor teksty poetyckie stanowią znaczną część podstawowego dokumentu, poświęconego środowisku naturalnemu Amazonii. Jest to tym bardziej prawdopodobna hipoteza, że obok niejednoznacznych, metaforycznych wyrażeń, pojawiają się sformułowania jednoznacznie podkreślające pluralizm

5 Por. Franciszek, Laudato si', dz. cyt., 89, 92, 138-139, 142, 240; Tenże, Querida Amazonia, Watykan 2020, 20, 23, 41; Tenże, Evangelii gaudium, Watykan 2013, 215-216.

6 Por. Tenże, Laudato si', dz. cyt., 1, 92; Tenże, Querida Amazonia, dz. cyt., 5, 8, 42-46, 55-56.

7 Por. M. Heller, Filozofia przyrody. Zarys historyczny, Kraków 2004, 129-148, 149-165; S. Kowalczyk, Zarys filozofii człowieka, Sandomierz 1990, 24-26; T. Ślipko, Zarys etyki szczegółowej, t. 2, Kraków 2002, 24-58. 
i gradualizm bytów, istniejących w przyrodzie i świecie realnym, świadczące o transcendencji Boga w stosunku do stworzeń, obce deterministycznej i unifikującej wizji świata i człowiekå ${ }^{8}$.

Niejednoznacznego sposobu wypowiadania się unikają natomiast polscy tomiści, którzy troskę o precyzję języka traktują jako jeden z najważniejszych sposobów unaukowienia własnej myśli ${ }^{9}$. Oni także rozpatrują przyrodę oraz związaną z nią sferę cywilizacyjno-kulturową z perspektywy holistycznej jako system, organizm, ale swoisty. Jedność organiczna jest tu rozumiana w sensie analogicznym, ponieważ sieć realnych związków przyczynowych nie zawsze ma charakter deterministyczny, a w obrębie bytów realnych - jakkolwiek nie ma pomiędzy nimi ostrych granic - dostrzega się odrębności ze względu na ich indywidualność, niepowtarzalność, względną autonomię. Dlatego obraz świata w wizji tomistycznej nie jest przejawem ani monizmu, ani dualizmu, ale pluralizmu, w którym zakłada się różnorodność rzeczy i zjawisk, ich hierarchię jako podstawę jakościowania różnic pomiędzy człowiekiem a innymi bytami, istniejącymi realnie (np. pomiędzy człowiekiem a zwierzętami i roślinami). Idee pluralizmu i hierarchii bytów uzasadnia się przy tym racjami przedmiotowymi: sposobem istnienia bytu, charakterem aktu determinującego jego istotę, w której podstawową funkcję spełnia forma substancjalna (dusza) jako wewnętrzna zasada organizacji materii. W ujęciu tomistycznym nie ma też podstaw do deifikacji przyrody, ponieważ Bóg jest transcendentny w stosunku do stworzenia, a Jego relacja do świata polega na stwarzaniu (jako przyczyna sprawcza, wzorcza i celowa) i podtrzymywaniu w istnieniu ${ }^{10}$.

8 Por. Franciszek, Querida Amazonia, dz. cyt., 31, 48; Tenże, Laudato si', dz. cyt., 33-42, 84-92, 147, 151.

9 Por. S. Kamiński, M.A. Krąpiec, Z teorii i metodologii metafizyki, Lublin 1962, 144-172, 250-254, 260-262, 282, 291-293.

10 Por. M.A. Krąiec, Rozmowy o metafizyce. A. Maryniarczyk rozmawia z M.A. Krapcem, Lublin 1997, 32, 80, 91-94, 98; S. Swieżawski, Święty Tomasz na nowo odczytany, Kraków 1983, 96-220; M. Jaworski, Metafizyka, Kraków 1998, 41-56; A. Maryniarczyk, Metafizyka 
W papieskiej wizji przyrody obecny jest także wątek aksjologiczny. Wyraża się on w przekonaniu, że środowisko naturalne i obecne w nim życie, wielość i różnorodność by tów, stanowią bezcenne dobro. Wartości, związane z przyrodą i z każdym z jej elementów, nawiązują do typowych prób ich klasyfikacji i hierarchizacji. Otóż jedne z tych dóbr mają charakter utylitarny i witalny, ponieważ zapewniają ludziom egzystencję od strony materialnej i biologicznej. Inne są typu poznawczego, ponieważ istnienie przyrody stwarza okazję do jej kontemplacji i osiągania tym sposobem mądrości, sprzyjającej postawie szacunku w stosunku do natury. Kolejne wartości dotyczą jej piękna, wpływającego na kształt sztuki, na proces odkrywania Boga oraz wzmacniania tożsamości wspólnot ludzkich ${ }^{11}$.

Aspekt aksjologiczny jest analogicznie rozumiany w refleksji tomistycznej, dla której czymś charakterystycznym jest umieszczanie tej problematyki w kontekście metafizycznym, czyli bytu jako takiego, będącego nośnikiem prawdy, dobra i piękna, pojętych na sposób transcendentalny, analogiczny, hierarchiczny, jako czegoś pochodnego od Absolutu. Wartości, związane z przyrodą, a także z cywilizacją, są traktowane jako dobra podstawowe, wspólne, ale nie najważniejsze i absolutne. Uważa się je za utylitarne, witalne, służebne wobec człowieka, zaspakajające jego elementarne potrzeby, dostarczające mu swoistych źródeł energii. Wartość przyrody jest przy tym stopniowalna, ponieważ występują w niej byty o różnym stopniu złożoności i doskonałości, z których niektóre posiadają cechy bliższe człowiekowi pod względem anatomicznym, fizjologicznym i behawioralnym. Niezależnie od ich pozycji w hierarchii, im wszystkim przypada rola służebna, podporządkowana człowiekowi w stopniu

w ekologii, dz. cyt., 27-32, 34-96, 116-127; Tenże, Zeszyty z metafizyki, z. 3, Lublin 1999, 83-88; J.M. Dołęga, Problematyka ochrony środowiska społeczno-przyrodniczego w sozologii i ekofilozofii, w: Ochrona środowiska w filozofii i teologii, red. J.M. Dołęga, J.W. Czartoszewski, Warszawa 1999, 22-25.

11 Por. Franciszek, Laudato si', dz. cyt., 1-2, 23-31, 33-34, 40-47, 95, 138-139, 215, 223, 225; Tenże, Querida Amazonia, dz. cyt., 16, 28-29, 31-32, 36-37, 41-49, 54, 57, 82. 
koniecznym dla jego życia, z czym wiąże się też obowiązek moralny ich poszanowana, ochrony, rozumnego używania ${ }^{12}$.

\section{KONCEPCJA CZŁOWIEKA}

Dla papieskiej teorii duchowości ekologicznej zasadnicze znaczenie posiada rozumienie bytu ludzkiego w myśl realistycznej antropologii filozoficznej. Takie przekonanie podzielają także przedstawiciele polskiego tomizmu, którzy podejście do przyrody wiążą ściśle z filozoficzną wizją człowieka, z prawdą o tym bycie. W obu tych przypadkach prawda ta jest niejednokrotnie ukazywana na tle stanowisk błędnych i nieprzydatnych dla właściwego stosunku do natury. Dostrzega się je w biocentryzmie, w skrajnych formach spirytualizmu oraz w niewłaściwie pojętym antropocentryzmie. W pierwszym przypadku występuje wprawdzie postawa szacunku lub czci dla wszelkich form życia i wobec środowiska naturalnego, ale w sposób nieuzasadniony pomija się fakt transcendencji osoby ludzkiej, co może sprzyjać postawie materializmu praktycznego i obojętności na sytuację człowieka w świecie przyrody. W skrajnym spirytualizmie, redukującym osobę ludzką do czynników duchowych, pomija się natomiast prawdę o jej cielesnym i przyrodniczym wymiarze, a tym samym potrzebę jego doceniania. W końcu niewłaściwie pojęty antropocentryzm przypisuje człowiekowi tak ważną i niczym nie uzasadnioną pozycję, że zajmuje niejako miejsce Boga, z którego to miejsca może uczynić przyrodę „tworzywem” nieograniczonej twórczości, osłabiającej jej wartość i powodującej jej bunt ${ }^{13}$.

12 Por. M.A. Krąpiec, Człowiek w kulturze, Lublin 1999, 22-42; A. Maryniarczyk, Metafizyka w ekologii, dz. cyt., 110-116, 128-155, 168-174; S. Kowalczyk, Człowiek w poszukiwaniu wartości. Elementy aksjologii personalistycznej, Lublin 2006, 178-181; T. Ślipko, A. Zwoliński, Rozdroża ekologii, Kraków 1999, 81, 129-143.

13 Por. T. Ślipko, A. Zwoliński, Rozdroża ekologii, dz. cyt., 87-88, 90-118, 123-129; A. Lemańska, Praktyczna filozofia przyrody alternatywa klasycznej filozofii przyrody?, Studia 
Właściwy pogląd na osobę ludzką jest w dość zgodny sposób przedstawiany przez obie strony. $Z$ tą różnicą, że tomiści akcentują substancjalny wymiar bytu ludzkiego za sprawą duszy jako ostatecznej podstawy wszelkich ludzkich cech oraz podobieństwa do Boga, wyższości nad innymi stworzeniami ziemskimi, racji szczególnej pozycji i godności człowieka w świecie, źródła należnych mu praw. Dokumenty papieskie, nie używając pojęcia duszy, zastępują je czasem bliskim mu znaczeniowo pojęciem natury ludzkiej, najczęściej jednak rozpatrują osobę w kategoriach przypadłościowych, czyli właściwości jej przysługujących ${ }^{14}$. Niezależnie jednak od bardziej substancjalnego czy fenomenalnego sposobu widzenia człowieka, dostrzega się w nim dwa zasadnicze wymiary, istotnie ważne dla oceny przyrody i potrzeby jej ochrony.

Pierwszy z nich uwzględnia fakt immanencji człowieka w świecie w sferze życia biologicznego, poznania, uczuć i działań; fakt, że byt ludzki nie jest elementem zewnętrznym wobec przyrody, ale w znacznym stopniu przynależy do niej jako jej część. Stanowi ona dla niego podstawę doczesnej egzystencji, zapewniającą mu środki do życia jako „potencjały naturalne”, z którymi należy żyć w swoistym przymierzu. Stąd jest dobrem wspólnym, powszechnym wszystkich ludzi wszystkich czasów, wymagającym szacunku, ochrony ${ }^{15}$. Teksty papieskie niekiedy do tego stopnia posuwają się w podkreślaniu tej immanencji, że pojawiają się kontrowersyjne, metaforyczne sformułowania o tym, że w „organizm” przyrody implantuje się sam czło-

Philosophiae Christianae 33(1997)1, 135-136; Franciszek, Laudato si', dz. cyt., 50, 55-56, 59, 105, 115-118, 122-124.

14 Por. M.A. Krąpiec, Rozmowy o metafizyce. A. Maryniarczyk rozmawia z M.A. Krąpcem, dz. cyt., 66-68; R. Darowski, Filozofia człowieka. Zarys problematyki, Kraków 1995, 9094; A. Maryniarczyk, Zeszyty z metafizyki, dz. cyt., 89-96; T. Ślipko, Zarys etyki ogólnej, Kraków 2002, 221-222; Franciszek, Laudato si', dz. cyt., 47, 58, 119, 155-162, 207, 240.

15 Por. Franciszek, Laudato si', dz. cyt., 138, 154-155, 202-215; Tenże, Querida Amazonia, dz. cyt., 11, 13, 28, 46; A. Lemańska, Filozofia przyrody a nauki przyrodnicze, Warszawa 1998, 43-54, 73; M.A. Krąpiec, Życie, w: Powszechna encyklopedia filozofii, t. 9, red. A. Maryniarczyk i in., Lublin 2008, 971-984. 
wiek, dostosowawszy się do jej elementów. Będąc z nią w symbiozie, utrzymuje braterskie relacje $\mathrm{z}$ innymi istotami oraz $\mathrm{z}$ otaczającym światem ${ }^{16}$.

Z immanencją związana jest ściśle transcendencja człowieka wobec przyrody i praw w niej obowiązujących, co jest dostrzegalne w tekstach papieskich oraz wyraźnie wyartykułowane w tomistycznej antropologii filozoficznej. Tomizm uzasadnia to w myśl idei substancjalizmu i personalizmu chrześcijańskiego, a papież Franciszek posługuje się argumentacją bardziej w duchu fenomenologicznym, nie pomijając jednak całkiem pojęcia natury ludzkiej, z którą wiąże różne właściwości, jak znajomość siebie; świadomość zasad moralnych; otwarcie na innych ludzi; uzdolnienie do miłości, dialogu, wielkoduszności i solidarności; odniesienie do Boga. Cechy te decydują o wartości i godności ludzkiej, podmiotowości ludów, uzasadniają prawa człowieka do samostanowienia, posiadania własności, własnego terytorium i obrony życia ${ }^{17}$. Z tej wyróżnionej pozycji osoby ludzkiej w świecie wynikają dla niej istotne zobowiązania. Jedne dotyczą stosunku do przyrody: ma być świadomym i odpowiedzialnym jej zarządcą, opiekunem, nie jedynym „panem”. Ma też prawo do kreatywności względem natury, ingerowania w jej stan, ale ze względu na jej dobro, przy zachowaniu norm etycznych i tylko wtedy, kiedy jest to konieczne dla życia ludzkiego. Inne zobowiązania dotyczą kierunku życia ludzkiego, mającego wpływ na stan przyrody. Jako podstawowe zadanie dla człowieka jawi się przede wszystkim udoskonalanie życia duchowego w aspekcie prawdy, dobra, piękna i relacji z Bogiem, sprawności rozumu i woli jako władz duszy, dzięki czemu realizuje się zasadnicze potrzeby ludzkie i dokonuje się formacja człowieka jako bytu, powołanego do doskonałości. Główna jego

16 Por. Franciszek, Laudato si', dz. cyt., 139, 221; Tenże, Querida Amazonia, dz. cyt., 20, 31, 32.

17 Por. I. Dec, Transcendencja człowieka w przyrodzie, Wrocław 1994, 11-12, 15; S. Kowalczyk, Zarys filozofii człowieka, dz. cyt., 33-311; 94; T. Styczeń, Wprowadzenie do etyki, Lublin 1993, 281; Franciszek, Querida Amazonia, dz. cyt., 12, 14, 26, 27, 51; Tenże, Laudato si', dz. cyt., 15, 56, 43, 115, 205; Tenże, Evangelii gaudium, dz. cyt., 214. 
aktywność ukierunkowana jest więc nie na rzeczy, ale na osoby, którym z racji szczególnej godności przysługuje powinność miłowania. Miłość osoby zakłada też poszanowanie środowiska naturalnego, które warunkuje życie osobowe ${ }^{18}$.

\section{POGLĄD NA KULTURĘ}

Kolejne wątki filozoficzne duchowości ekologicznej, pojawiające się $\mathrm{w}$ dokumentach papieskich oraz obecne w filozofii tomistycznej, związane są z kulturą, postrzeganą w ścisłej więzi z przyrodą, ale jednocześnie ją transcendującą. Wspólne obu ujęciom jest traktowanie tego szerokiego i zróżnicowanego obszaru rzeczywistości - obok dziedzictwa przyrodniczego - jako fundamentalnego dla człowieka punktu odniesienia, pełniącego rolę jego swoistych „korzeni”, osadzonych w realiach lokalnych; jako skarbu, sprzyjającego zachowaniu środowiska naturalnego, który winien być strzeżony analogicznie do potencjałów przyrodniczych ${ }^{19}$. W obszarze kultury wyróżnia się kilka jej podstawowych form, które są - poza wątkiem etycznym - zasadniczo zgodnie rozumiane w dokumentach Papieża i w tekstach tomistów.

Jedną z nich jest praca i jej wytwory. Stosunek do niej jest swoistą formą duchowości, uzyskiwanej dzięki m.in. filozofii, dającej podstawy do sformulowania systemu przekonań na istotę tego fenomenu, na jego zasadnicze formy i cele. To, co jest najważniejsze

18 Por. Franciszek, Laudato si', dz. cyt., 43, 48, 125-128, 146-152, 155-162; 236; Tenże, Querida Amazonia, dz. cyt., 49-50, 82; K. Wojtyła, Osoba i czyn, Kraków 1985, 217-222, 224-227; M.A. Krąpiec, Człowiek w kulturze, dz. cyt., 21-188; T. Ślipko, Zarys etyki ogólnej, dz. cyt., 61-73; Z.J. Zdybicka, Człowiek i religia, Lublin 1977, 117-202, 282-290; J. Łukomski, Podstawy chrześcijańskiej etyki środowiska naturalnego, w: Ochrona środowiska w filozofii i teologii, dz. cyt., 177, 179-191.

19 Por. M.A. Krąpiec, Człowiek w kulturze, dz. cyt., 137-151, 173-181; P. Jaroszyński, Filozofia kultury, w: Powszechna encyklopedia filozofii, t. 3, red. A. Maryniarczyk i in., Lublin 2002, 478-480; Franciszek, Laudato si', dz. cyt., 4, 43, 143-146; Tenże, Querida Amazonia, dz. cyt., 7, 13. 
i wspólne dla filozofii tomistycznej i dokumentów papieskich, to szerokie rozumienie tego zjawiska oraz jego sensu, traktowanie go jako podstawowego przejawu natury człowieka, sposobu realizacji jego podstawowego powołania. W kontekście ekologii szczególnie ważny jest sens pracy. Nie ma on wiele wspólnego z nowożytną ideą postępu zrealizowaną we współczesnej cywilizacji, która - obok wielu osiągnięć - odpowiedzialna jest też za znaczne zniszczenie środowiska naturalnego. Postęp ów oderwał bowiem człowieka od prawdy o nim, od idei jego osobowego doskonalenia się i spełnienia się, a połączył go głównie z maksymalnym wykorzystaniem zasobów przyrody w procesie produkcji coraz to większej ilości coraz doskonalszych rzeczy, służących osiąganiu maksymalnego zysku i konsumpcji, przedłużaniu i ułatwianiu życia za wszelką cenę. Ta nowożytna idea postępu pominęła natomiast właściwie pojęty sens pracy, formułowany w filozofii klasycznej od czasów starożytności, gdzie główna uwaga skierowana jest na doskonalenie człowieka, na wszechstronny rozwój osobowy, postęp w zakresie kultury duchowej, odpowiadającej godności człowieka i sprzyjającej zachowaniu dziedzictwa przyrodniczego. Jakkolwiek praca umożliwia zaspokojenie potrzeb o charakterze materialnym, to w każdym razie nie są one jedynym celem - mają one służyć wartościom duchowym ${ }^{20}$.

Kolejne wątki filozoficzne pojawiają się w związku z poznawczą relacją człowieka do siebie i świata, w toku której zdobywa wiedzę i wyraża ją w różnych formach. Teksty papieskie szczególnie podkreślają rolę głębokich tradycji o charakterze mądrości, osiąganych dzięki doświadczeniu życiowemu oraz kontemplacji przyrody, co ma ogromny wpływ na życie osobiste, społeczne oraz na odpowiedni stosunek do przyrody, na ocenę jej wartości. Nie zapomina się też o roli filozofii jako usystematyzowanej nauki, która uczy głębokiego

20 Por. Franciszek, Laudato si', dz. cyt., 124-129, 137, 195; Tenże, Querida Amazonia, dz. cyt., 9-14; Jan Paweł II, Laborem exercens, Watykan 1981, 6, 9, 10, 24-27; J.W. Gałkowski, Praca i człowiek, Warszawa 1980, 104-300; A. Maryniarczyk, Metafizyka ekologii, dz. cyt., 14-19. 
myślenia i mądrego życia, a jej charakter krytyczny pozwala m.in. na odrzucenie irracjonalnej wiary w postęp naukowo-techniczny oraz w nieograniczone możliwości człowieka, odpowiedzialnej w znacznym stopniu za katastrofalny stan środowiska naturalnego ${ }^{21}$. Spojrzenie ze strony filozofii tomistycznej jest w tej kwestii analogiczne, ponieważ dla właściwego stosunku człowieka do rzeczywistości realnej, w tym i do przyrody, uwzględnia się w niej kluczowe znaczenie wartościowego poznania, obecnego m.in. w klasycznej filozofii przyrody oraz w metafizyce, będącej podstawą mądrości ${ }^{22}$.

Następny temat filozoficzny, ważny dla teorii duchowości ekologicznej, związany jest $\mathrm{z}$ wrażliwością bytu ludzkiego na piękno, odkrywane w przyrodzie i ucieleśniane w twórczości artystycznej, $\mathrm{w}$ tworach szeroko rozumianej sztuki. Jest ono podobnie rozumiane $\mathrm{w}$ tomizmie $\mathrm{i}$ w dokumentach papieskich, jeśli chodzi o jego rolę w kwestii ekologicznej. Urzeczywistniane bowiem np. w literaturze (zwłaszcza w poezji) lub muzyce, pozwala nie tylko odkryć Boga, zachować tożsamość wspólnotową, ale też ocalić przyrodę, chroniąc ją przed rabunkową i niszczycielską działalnością ${ }^{23}$.

Najważniejszym jednak elementem kulturowym w papieskiej teorii duchowości ekologicznej jest moralność, którą wiąże się z sumieniem jako koniecznym elementem natury człowieka pozwalającym na „dobre życie”. Polega ono na utrzymywaniu właściwych relacji z innymi ludźmi oraz ze środowiskiem naturalnym jako dobrem, które należy zachować w odpowiednim stanie dla współczesnych oraz przyszłych pokoleń. Troska o człowieka oraz troska o ekosystemy są tu więc najściślej powiązane. Właściwa bowiem etyka,

21 Por. Franciszek, Laudato si', 4, 19, 47, 60, 63, 101-115, 138-139, 147, 199-215; Tenże, Querida Amazonia, dz. cyt., 36-37, 52; M.A. Krąpiec, Człowiek w kulturze, dz. cyt., 22-42.

22 Por. A. Maryniarczyk, Metafizyka w ekologii, dz. cyt., 19-32, 77-78; J.M. Dołęga, Człowiek w zagrożonym środowisku. Z podstawowych zagadnień sozologii, Warszawa 1998, 50-52.

23 Por. Franciszek, Laudato si', dz. cyt., 215, 223, 225; Tenże, Querida Amazonia, dz. cyt., 32, 54, 57, 82; A.B. Stępień, Propedeutyka estetyki, Warszawa 1975, 13-52, 121-135; S. Kowalczyk, Człowiek w poszukiwaniu wartości..., dz. cyt., 178-181. 
uwzględniająca tradycyjne cnoty, jak miłość bliźniego, umiarkowanie, jest dobrem odpowiednim dla osoby ludzkiej oraz sprzyja ochronie jego środowiska naturalnego. Natomiast etyka pozbawiona takich wartości (konsumpcjonizm, hedonizm czy egoizm) prowadzi nie tylko do degradacji życia ludzkiego, ale też do zniszczenia przyrody ${ }^{24}$.

W papieskiej myśli pojawiają się jednak dwa elementy, które budzą zastrzeżenia ze strony etyki tomistycznej. Jedno dotyczy zrównania troski o człowieka $z$ troską o środowisko naturalne. Drugie - podważenia uniwersalnego charakteru zasad etyczno-religijnych, nie stosujących się do wszystkich ludzi w jednakowym stopniu ze względu na uprzywilejowaną pozycję ludzi biednych oraz naczelną cnotę miłosierdzia. Taka więc podstawowa kategoria, „jakość życia” człowieka, zostaje zrelatywizowana do zamkniętych grup ludzkich w pewnych obszarach geograficznych, w których obowiązują specyficzne światopoglądy, wizje świata, wierzenia i praktyki religijne, symbole, zwyczaje, style życia i wartości ${ }^{25}$. Poglądy takie traktuje się w tomizmie jako pewną formę naturalizmu, przykład znacznego odejścia od dotychczas pojmowanego prawa moralnego, traktowanego jako dobro absolutne, czyli powszechne i niezmienne, wieczne, ugruntowane na niezmiennej naturze człowieka i na Bogu jako fundamencie bytu i ostatecznej normie moralności ${ }^{26}$.

24 Por. Franciszek, Querida Amazonia, dz. cyt., 6-10, 13-17, 20-25, 42, 52-53, 71, 97; Tenże, Laudato si', dz. cyt., 47-52, 101, 105-114, 155-162, 203-208, 218; Tenże, Evangelii gaudium, dz. cyt., 197.

25 Por. Tenże, Querida Amazonia, dz. cyt., 40, 48.

26 Por. Jan Paweł II, Veritatis splendor, Watykan 1993, 95, 96; M.A. Krąiec, Człowiek i prawo naturalne, Lublin 1993, 29-30, 190-191, 207; A. Andrzejuk, Filozofia moralna w tekstach Tomasza z Akwinu, Warszawa 1999, 14, 16, 93; M. Gogacz, Wprowadzenie do etyki chronienia osób, dz. cyt., 22-24, 44-45; T. Ślipko, Zarys etyki ogólnej, dz. cyt., 51, 292-328; T. Styczeń, Wprowadzenie do etyki, dz. cyt., 13-21, 282-283. 


\section{FILOZOFIA RELIGII I FILOZOFIA BOGA}

Dla papieskiej teorii duchowości ekologicznej i wizji tomistycznej zasadnicze znaczenie posiada rodzacy postawy proekologiczne filozoficzny pogląd na religię i Boga. W poglądzie tym wyrażona została idea, że w zjawisku religijności przejawia się najwyższy stopień transcendencji osoby ludzkiej w świecie, uobecnia się fundamentalny dla niej punkt odniesienia w życiu, ujawniają się jej najważniejsze „korzenie”. W takim odniesieniu ukazują się człowiekowi nowe perspektywy życia, motywacje, dające mu zaspokojenie najwyższych potrzeb, nową jakość życia, zorientowaną nie na potrzeby materialne, ale duchowe, istotnie ważne w kontekście ochrony przyrody. Istnieje tu zgoda z myślą tomistyczną, że relacja osoby ludzkiej z Bogiem różnicuje się ze względu na dwa poziomy spotkania, odpowiednio do sposobu poznania rozumowego i wiary chrześcijańskiej w wersji katolickiej. Daje to w rezultacie nieco inne obrazy Boga i typy duchowości ${ }^{27}$.

Czymś wspólnym dla teodycei tomistycznej i refleksji papieskiej jest przekonanie, że świat kosmosu jest swoistym przekaźnikiem objawienia (naturalnego), źródłem poznania istnienia i natury Stwórcy, prowadzącym człowieka do wyrażania go w swoistym kulcie. Dzięki takiemu „pośrednictwu” przyroda staje się „miejscem teologicznym” spotkania z Bogiem, objawiającym się jako Opatrzność, Piękno, a nawet jako Trójca Święta. Odkrywanie Go dzięki obserwacji i kontemplacji przyrody oraz relacje z Nim sprzyjają też ochronie przyrody, ponieważ jest ona postrzegana nie jako własność człowieka, ale jako należąca do Tego, który dał ją człowiekowi w mądre użytkowanie ${ }^{28}$.

27 Por. Franciszek, Laudato si', 199-201; W. Granat, Teodycea. Istnienie Boga i Jego natura, Poznań 1960, 179-182, 351-353, 375-378, 398-459; S. Swieżawski, Święty Tomasz na nowo odczytany, dz. cyt., 80-89; S. Kowalczyk, Odkrywanie Boga. Centralne problemy filozofii Boga, Sandomierz 1981, 41-62, 285-308.

28 Por. Franciszek, Laudato si', dz. cyt., 222-227, 235-236, 238-240; Tenże, Querida Amazonia, dz. cyt., 32, 42, 54, 57, 82, 97; W. Granat, Teodycea, dz. cyt., 224-289; K. Wojtyła, 
W dokumentach papieskich oraz na gruncie tomistycznej filozofii Boga i filozofii religii rozważa się jeszcze inny typ poznania Boga i relacji z Nim - w tzw. życiu nadprzyrodzonym. Jest ono owocem bezpośredniej, historycznej inicjatywy Boga, Jego łaski, wznoszącej człowieka na wyższy poziom życia duchowego. Wyraża się ono w żywej i osobowej więzi przyjaźni i miłości z Trójcą Świętą, w uczestnictwie w życiu Kościoła, w doświadczaniu Boga jako kogoś bliskiego, miłosiernego, rozpoznawanego jako osobowe „Ty”29. Taki obraz Boga i odpowiedni stosunek do Niego - wyrażany w kulcie i postawie miłości - spełniają najważniejsze dla życia ludzkiego funkcje. Prowadzą mianowicie do uświęcenia i zbawienia człowieka, otwierają przed nim możliwości życiowe najbardziej wzbogacające osobę ludzką i nadające sens jej życiu. Nie znoszą one innych wartości (natury, świata rzeczy), tylko ustanawiają ich nową i właściwą hierarchię ${ }^{30}$ Tym samym osiąga się cele ekologiczne, podkreślane szczególnie w nauczaniu papieskim, w którym komponent ekologiczny jest wpisany w istotę religii, w tak typowe dla niej zjawiska, jak wspólne świętowanie i odpoczynek, asceza i nawrócenie. Religia pełni w tym ujęciu funkcję „światła” dla ekologii, moc zachowawczą przyrody, normę, nakazującą umiar w korzystaniu z bogactw natury i nakierowującą ludzi na dobra duchowe, wieczne ${ }^{31}$. Dokonuje się to

O poznawalności i poznawaniu Boga..., dz. cyt., 54-57; M. Jaworski, Bóg filozofów i Bóg wierzących, w: Wybór pism filozoficznych, red. K. Mikucki, Episteme, t. 28, Olecko 2003, 165-167, 169.

29 Por. K. Wojtyła, O poznawalności i poznawaniu Boga. Zarys zagadnień, Kraków 2000, 51-84; M Gogacz, Poszukiwanie Boga. Wykłady z metafizyki absolutnego istnienia, Warszawa 1970, 65-68, 150-152; Franciszek, Laudato si', dz. cyt., 33, 100, 222-227, 243-244; Tenże, Querida Amazonia, dz. cyt., 55, 71-73, 75-105; Tenże, Gaudete et exultate, Watykan 2018, 43-46, 47-62.

30 Por. K. Wojtyła, Elementarz etyczny, Lublin 1999, 53-55; M.A. Krąpiec, Odzyskać świat realny, Lublin 1999, 301, 303-307; Franciszek, Querida Amazonia, dz. cyt., 6, 61-65, 74, 76, 84; Tenże, Laudato si', 219-227.

31 Por. Franciszek, Laudato si', dz. cyt., 6, 62-100, 204, 216-238, 243-245; Tenże, Querida Amazonia, dz. cyt., 6, 18, 22, 33, 41, 60, 76, 80, 81, 83, 91-93; Tenże, Lumen fidei, Watykan 2013, 55; R. Sadowski, Filozoficzny spór o rolę chrześcijaństwa w kwestii ekologicznej, 
szczególnie w życiu konsekrowanym, którego celem jest świętość, osiągana poprzez harmonię życia z samym sobą, z Bogiem, ludźmi i naturą, traktowaną nie jako przedmiot użycia, ale dobro, do którego należy się odnosić z szacunkiem. Modelem takiej postawy jest tradycja monastyczna, a także w sposób szczególny przykład św. Franciszka z Asyżu, którego stosunek do przyrody był konsekwencją głębokiego życia duchowego, osiąganego w kontemplacji, w mistyce, w prostocie życia braterskiego, w ubóstwie, w poświęceniu się służbie na rzecz Boga i ludzi ${ }^{32}$.

Obok ogólnej zgody w sprawie kluczowego znaczenia religii i koncepcji Boga dla kwestii ekologicznych, pojawiały się czasem w obu rozpatrywanych ujęciach pewne różnice, analogiczne do kwestii etycznych. Mianowicie: w koncepcji papieskiej podaje się nieraz w wątpliwość monolityczność zasad religijnych, ich uniwersalność i niezmienność, ukazując ich historyczny charakter, uzależniony od kontekstu regionalnego, kulturowego i czasowego. Jest to znak odejścia m.in. od tradycji filozofii tomistycznej, która głównym zasadom chrześcijańskim przypisywała stałość i uniwersalność z racji niezmienności Boga, objawiającego się w naturze i słowie ${ }^{33}$.

\section{PODSUMOWANIE}

W artykule podjęto próbę porównania treści filozoficznych, zawartych w teorii duchowości ekologicznej papieża Franciszka z myślą tomistyczną, rozwijaną współcześnie przez jej polskich przedstawicieli. Treści te dotyczą wielu dyscyplin, ponieważ tego typu duchowość

Warszawa 2015, 102-286, 288-362, 365; T. Ślipko, Ekologiczna doktryna Kościoła, w: T. Ślipko, A. Zwoliński, Rozdroża ekologii, dz. cyt., 9-181.

32 Por. Franciszek, Laudato si', dz. cyt., 10-12, 53, 125-126; Tenże, Querida Amazonia, dz. cyt., 77, 78, 92, 95.

33 Por. Franciszek, Evangelii gaudium, dz. cyt., 43, 47, 49; Tenże, Christus vivit, Watykan 2019, 41; M.A. Krąpiec, Odzyskać świat realny, dz. cyt., 182-186, 220-224; Tenże, Filozofia co wyjaśnia? Filozofia w teologii, Lublin 2000, 218-219, 223-224. 
uwzględnia stosunek człowieka do wszystkich podstawowych sfer rzeczywistości realnej. $\mathrm{W}$ toku analizy obu stanowisk zauważono liczne analogie, a także pewne rozbieżności.

Podobieństwa dotyczą najpierw filozoficznej wizji przyrody, którą widzi się w perspektywie holistycznej jako system zróżnicowany i złożony, połączony siecią powszechnych i koniecznych relacji, mający ścisłe związki $z$ całą rzeczywistością stworzoną i wykreowaną przez człowieka, a rozpatrywany od strony aksjologii stanowi bezcenną wartość. Analogie odnoszą się do rozumienia bytu ludzkiego, w którego strukturze wyróżnia się wymiar immanentny (cielesny) i transcendentny (duchowy). Zasadnicza zgodność panuje następnie w kwestii pojęcia kultury, takich jej podstawowych form, jak praca, nauka, sztuka i moralność. $W$ podobny sposób rozumie się w końcu religię i Boga na płaszczyźnie poznania naturalnego i nadprzyrodzonego.

Różnice pojawiają się najpierw w sposobie widzenia przyrody z uwagi na obce tomizmowi wtręty, wskazujące na jej antropomorfizację, sakralizację, animizm czy deifikację, przy zastrzeżeniu, że mogą to być przejawy „romantycznego” sposobu podejścia do niej. Następna rozbieżność dotyczy papieskiej wizji człowieka, w której istnieje ślad zacierania transcendencji człowieka wobec przyrody, mocno podkreślanej przez tomizm. Kolejna różnica zdań jest zauważana w kwestiach etycznych, ponieważ w tekstach Franciszka są sformułowania, wskazujące na zrównanie troski o człowieka z troską o środowisko naturalne oraz podważające uniwersalny charakter zasad etycznych, co jest sprzeczne $z$ etyką tomistyczną. Ta sama uwaga odnosi się do papieskiego rozumienia zasad religijnych, które nie stosują się do wszystkich ludzi w jednakowym stopniu. 


\section{BIBLIOGRAFIA}

Andrzejuk A., Filozofia moralna w tekstach Tomasza z Akwinu, Wydawnictwo NAVO, Warszawa 1999.

Darowski R., Filozofia cztowieka. Zarys problematyki, Wydawnictwo WAM, Kraków 1995.

Dec I., Transcendencja cztowieka w przyrodzie, Wydawnictwo Papieskiego Wydziału Teologicznego, Wrocław 1994.

Dołęga J.M., Człowiek w zagrożonym środowisku. Z podstawowych zagadnień sozologii, Wydawnictwo ATK, Warszawa 1998.

Dołęga J.M., Problematyka ochrony środowiska spoteczno-przyrodniczego w sozologii i ekoflozofii, w: Ochrona środowiska w fllozofii i teologii, red. J.M. Dołęga, J.W. Czartoszewski, Wydawnictwo ATK, Warszawa 1999, 10-26.

Franciszek, Christus vivit, Libreria Editrice Vaticana, Watykan 2019.

Franciszek, Evangelii gaudium, Libreria Editrice Vaticana, Watykan 2013.

Franciszek, Gaudete et exultate, Libreria Editrice Vaticana, Watykan 2018.

Franciszek, Laudato si', Libreria Editrice Vaticana, Watykan 2015.

Franciszek, Lumen fidei, Libreria Editrice Vaticana, Watykan 2013.

Franciszek, Querida Amazonia, Libreria Editrice Vaticana, Watykan 2020.

Gałkowski J.W., Praca i cztowiek, Wydawnictwo Pax, Warszawa 1980.

Gogacz M., Poszukiwanie Boga. Wyktady z metafizyki absolutnego istnienia, Wydawnictwo ATK, Warszawa 1970.

Gogacz M., Wprowadzenie do etyki chronienia osób, red. A. Andrzejuk, Wydawnictwo NAVO, Warszawa 1995.

Granat W., Teodycea. Istnienie Boga i Jego natura, Wydawnictwo Pallottinum, Poznań 1960.

Heller M., Filozofia przyrody. Zarys historyczny, Znak, Kraków 2004.

Jan Paweł II, Fides et ratio, Libreria Editrice Vaticana, Watykan 1998.

Jan Paweł II, Laborem exercens, Libreria Editrice Vaticana, Watykan 1981.

Jan Paweł II, Veritatis splendor, Libreria Editrice Vaticana, Watykan 1993.

Jaroszyński P., Filozofia kultury, w: Powszechna encyklopedia fllozofii, t. 3, red.

A. Maryniarczyk i in., Polskie Towarzystwo Tomasza z Akwinu, Lublin 2002, 478-480.

Jaworski M., Bóg filozofów i Bóg wierzacych, w: Wybór pism flozoficznych, red. K. Mikucki, Episteme, t. 28, Wydawnictwo AUM, Olecko 2003, 165-176.

Jaworski M., Metafizyka, Wydawnictwo PAT, Kraków 1998.

Kamiński S., Krąpiec M.A., Z teorii i metodologii metafizyki, TN KUL, Lublin 1962. 
Kowalczyk S., Cztowiek w poszukiwaniu wartości. Elementy aksjologii personalistycznej, Wydawnictwo KUL, Lublin 2006.

Kowalczyk S., Odkrywanie Boga. Centralne problemy filozofii Boga, Wydawnictwo Diecezjalne, Sandomierz 1981.

Kowalczyk S., Zarys filozofii cztowieka, Wydawnictwo Diecezjalne, Sandomierz 1990.

Krąpiec M.A., Cztowiek i prawo naturalne, Wydawnictwo KUL, Lublin 1993

Krąpiec M.A., Cztowiek w kulturze, Wydawnictwo KUL, Lublin 1999.

Krąpiec M.A., Filozofia co wyjaśnia? Filozofia w teologii, Wydawnictwo KUL, Lublin 2000.

Krąpiec M.A., Odzyskać swiat realny, Wydawnictwo KUL, Lublin 1999.

Krąpiec M.A., Rozmowy o metafizyce. A. Maryniarczyk rozmawia z M.A. Krapcem, Stowarzyszenie Młodzieżowe „Żyć i Poznawać”, Lublin 1997.

Krąpiec M.A., Stowo wstępne, w: A. Maryniarczyk, Metafizyka w ekologii, Wydawnictwo KUL, Lublin 1999, 9-11.

Krąpiec M.A., Życie, w: Powszechna encyklopedia filozofii, t. 9, red. A. Maryniarczyk i in., Polskie Towarzystwo Tomasza z Akwinu Lublin, 2008, 971-984.

Lemańska A., Filozofia przyrody a nauki przyrodnicze, Wydawnictwo ATK, Warszawa 1998.

Lemańska A., Praktyczna fllozofia przyrody alternatywa klasycznej filozofii przyrody?, Studia Philosophiae Christianae 33(1997)1, 133-138.

Łukomski J., Podstawy chrześcijańskiej etyki środowiska naturalnego, w: Ochrona środowiska w filozofii i teologii, red. J.M. Dołęga, J.W. Czartoszewski, Wydawnictwo ATK, Warszawa 1999, 177-202.

Maryniarczyk A., Metafizyka ekologii, Wydawnictwo KUL, Lublin 1999.

Maryniarczyk A., Zeszyty z metafizyki, z. 3, SITA, Lublin 1999.

Sadowski R., Filozoficzny spór o rolę chrześcijaństwa w kwestii ekologicznej, Towarzystwo Naukowe Franciszka Salezego, Warszawa 2015.

Stępień A.B., Propedeutyka estetyki, Wydawnictwo ATK, Warszawa 1975.

Styczeń T., Wprowadzenie do etyki, TN KUL, Lublin 1993.

Swieżawski S., Święty Tomasz na nowo odczytany, Znak, Kraków 1983.

Ślipko T., A. Zwoliński, Rozdroża ekologii, Wydawnictwo WAM, Kraków 1999.

Ślipko T., Zarys etyki ogólnej, Wydawnictwo WAM, Kraków 2002.

Ślipko T., Zarys etyki szczegótowej, t. 1, Wydawnictwo WAM, Kraków 1982.

Ślipko T., Zarys etyki szczegótowej, t. 2, Wydawnictwo WAM, Kraków 2002.

Wojtyła K, Osoba i czyn, Polskie Towarzystwo Teologiczne, Kraków 1985.

Wojtyła K., Elementarz etyczny, TN KUL, Lublin 1999. 
Wojtyła K., O poznawalności i poznawaniu Boga. Zarys zagadnień, Instytut Jana Pawła II, Kraków 2000.

Wróblewski Z., Ekologii filozofia, w: Powszechna encyklopedia filozofi, t. 3, red. A. Maryniarczyk i in., Polskie Towarzystwo Tomasza z Akwinu, Lublin 2002, 67-77.

Zdybicka Z.J., Cztowiek i religia, TN KUL, Lublin 1977.

\title{
THE PHILOSOPHICAL DIMENSION OF POPE FRANCIS'S THEORY OF ECOLOGICAL SPIRITUALITY IN THE LIGHT OF THOMISTIC PHILOSOPHY
}

\begin{abstract}
This article is an attempt to isolate and describe the philosophical aspects of Pope Francis's theory of ecological spirituality and compare them with Thomistic thought, as developed by Polish philosophers in modern times. This is something philosophers have already noticed, because this type of spirituality is about man's relationship with the most generally understood reality, i.e. himself, nature, culture and religion. Our examination of both positions will reveal numerous analogies as well as some differences in their understanding of nature, the human person, culture (ethics) and religion, which at least partly can be explained by the ambiguity of some papal formulations.
\end{abstract}

Keywords: ecological spirituality; Pope Francis; Thomism; nature; man; culture; religion

\author{
Kazimierz Mikucki \\ Instytut Teologiczny im. Św. Józefa Bilczewskiego, Lviv/Lwów, Ukraina \\ (Theological Institute of Saint Joseph Bilczewski, Lviv, Ukraine) \\ ORCID: https://orcid.org/0000-0001-5589-2681 \\ mikkaz@lviv.farlep.net
}

DOI: $10.21697 /$ spch.2020.56.4.12 